\title{
FINANCIJSKI POKAZATELJI POSLOVANJA VELIKIH BANAKA U REPUBLICI HRVATSKOJ
}

\section{FINANCIAL PERFORMANCE INDICATORS OF LARGE BANKS IN THE REPUBLIC OF CROATIA}

SAŽETAK: Hrvatski bankovni sektor karakterizira visok stupanj koncentracije. Nekoliko velikih međunarodnih bankovnih grupacija drži glavninu imovine hrvatskog bankovnog sektora kroz vlasništvo najvećih banaka koje imaju dominantnu ulogu i relativno značenje u bankovnom sektoru, ali i u ukupnom financijskom sustavu s obzirom na njegovu izrazitu bankocentričnost i značenje bankovnih kredita kao najvažnijih eksternih izvora financiranja. Iz navedenog proizlazi i važna ekonomska uloga velikih banaka u Republici Hrvatskoj. U posljednjem desetljeću hrvatske su banke, kao i drugdje u svijetu, poslovale u iznimno izazovnom financijskom i makroekonomskom okruženju. Prelijevanje financijske krize 2008. godine na ekonomsku sferu u Republici Hrvatskoj je za posljedicu imalo dugotrajnije razdoblje recesije, koja se značajnije odrazila na poslovnu politiku, pokazatelje poslovanja i konkurentnost banaka. Postrožavanje kreditnih uvjeta i suzdržanost od kreditiranja dodatno su produbili razmjere krize, a u postkriznom razdoblju banke su primarno bile orijentirane na čišćenje bilanci od loših kredita. Pristupanje Republike Hrvatske Europskoj uniji obilježilo je stupanje na snagu i ostatka povezanih regulatornih odredbi osim primjene strožih regulatornih pravila uspostavljenih kao odgovor na krizu. U fokusu analize provedene za potrebe ovog rada je uloga, položaj i poslovanje velikih hrvatskih banaka kako bi se utvrdila uspješnost njihova poslovanja, ali i utjecaj na rezultate poslovanja cjelokupnog hrvatskog bankovnog sektora s obzirom na to da zauzimaju visok udio u ukupnoj imovini. Za tu svrhu, primijenjena je deskriptivno-statistička analiza izabranih financijskih pokazatelja poslovanja pet velikih hrvatskih banaka u privatnom vlasništvu u razdoblju od 2012. do 2019. godine, a rezultati su interpretirani u usporedbi s financijskim pokazateljima ostvarenim na razini cjelokupnog bankovnog sektora uzimajući u obzir sve specifičnosti poslovnog okruženja u promatranom razdoblju. Dodatno se komparativnom analizom utvr-

Doc. dr. sc. Branka Tuškan Sjauš, Ekonomski fakultet Zagreb, Trg J.F.Kennedy-a 6, Zagreb

Robert Zubanović, mag.oec. 
đuje koje velike banke pritom prednjače uz ukazivanje na čimbenike i poslovnu strategiju, koji se detektiraju kao potencijalno najznačajniji razlog ostvarenih rezultata i pokazatelja poslovanja. Rezultati istraživanja omogućuju bolje razumijevanje poslovnih rezultata, uloge i značenja velikih banaka u hrvatskom financijskom sustavu i njihovo značenje za cjelokupnu ekonomiju, posebice u razdobljima izraženijih promjena i nestabilnosti na financijskom tržištu te u makroekonomskom okruženju.

KLJUČNE RIJEČI: velike banke, poslovanje, financijski pokazatelji, kriza, Hrvatska

ABSTRACT: Croatian banking sector has high level of concentration. Few large international banking groups dominate in the total banking sector asset trough the ownership of largest Croatian banks which have a dominant role and significance in the total banking sector and in total financial sectorasnoticeably bank-orientated with bank loans asthe most important external source of funding for the economy. For that reason large banks in Croatiaplay important role in the economy. However, Croatian banks operated in challengingfinancial and macroeconomic environment in the last decade as well as banks in many other countries. 2008 financial crisis spill over effect on the economy had for consequence more prolonged period of recession. Moreover, stricter regulatory rules for banks as a consequence of crisis effects were accompanied by new regulatory rules, which came into force by Croatia's accession to the European Union in 2013. Consequently, the banking sector experienced significant changes and adjustments as well, since those circumstances strongly impacted banks' business policy, performance and competitiveness. More rigid credit policy and decline in lending activities emphasized crisis effects. For that reason banks in post-crisis period were oriented on cleaning nonperforming loans from the balance sheets. This analysis is focused on the role, position and business performance of large banks in Croatiain order to determine their financial performance efficiency and impact on the total banking sector performance since large banks dominate in total asset structure.For that purpose, descriptive statistics analysis is applied on chosen accounting and other financial performance indicators of 5 large private banks in the period 2012-2019. Analysis results are interpreted in comparison to the results for total banking sector and taking into consideration all specific circumstances in business environment. Additionally, comparative analysis of financial performance indicators is made in order to rank large banks according to the level of efficiency and to point out specific business strategy and other factors that are detected as the most important for obtained results. Research results obtained herein could help in better understanding of business performance and role of large banks in the total financial sector and economy in times of dynamic and unstable financial or macroeconomic environment.

KEY WORDS: large banks, financial performance, indicators, crisis, Croatia

\section{UVOD}

Razdoblje nakon izbijanja financijske krize 2008. godine obilježile su brojne promjene i prilagodbe novonastalim okolnostima i posljedicama krize u bankovnim sustavima na globalnoj razini. Najvažnije promjene odnosile su se na izmjene i postrožavanje regulator- 
nog okvira poslovanja banaka u dijelu upravljanja rizicima radi sprečavanja težih posljedica i šteta u budućem poslovanju banaka, poučeni iskustvom i financijskim te socioekonomskim posljedicama spomenute krize. Jedna od izravnih posljedica krize u posljednjem desetljeću je zamjetniji trend smanjenja broja banaka nakon 2009. godine, uslijed okrupnjavanja, propadanja i izostanka osnivanja novih banaka. Okrupnjavanje banaka posljedica je prilagodbe poslovanja i težnje za poboljšanjem efikasnosti i profitabilnosti banaka uslijed destabilizacije makroekonomskog okruženja radi prelijevanja financijske krize na ekonomije kao i ostalih specifičnih uvjeta poslovanja u tom izazovnom razdoblju. Brojne male banke nisu uspijevale samostalno opstati na tržištu u takvim uvjetima te su bile prisiljene na procese okrupnjavanja koje su predvodile veće banke jer bi u suprotnom nestajale $\mathrm{s}$ tržišta. Brojne velike banke na ovaj su način iskoristile priliku i dodatno ojačale svoju tržišnu poziciju i povećale koncentraciju u izabranim bankovnim sustavima. Ipak, u nekim regijama, primjerice u Jugoistočnoj Europi, pojedine su međunarodne bankovne grupacije zbog promjene poslovne politike uzrokovane povećanom izloženošću rizicima značajnije smanjile svoje tržišne udjele.

Hrvatski bankovni sustav u posljednjem je desetljeću doživio slične promjene i prilagodbe, a najznačajniju ulogu u procesu smanjenja broja banaka kroz okrupnjavanje imale su najveće banke koje su dio ili podružnice velikih bankovnih grupa sa sjedištem u nekoj od zemalja EU-a. Svrha ovog rada je prikazati tranziciju poslovanja i položaja velikih hrvatskih banaka u razdoblju od 2012. godine do 2019. godine. Za tu svrhu, u radu će biti prikazani tijek okrupnjavanja i rezultati deskriptivno-statističke i komparativne analize izabranih pokazatelja poslovanja na uzorku od pet velikih hrvatskih banaka te njihova usporedba s rezultatima analize poslovanja čitavog hrvatskog bankovnog sektora, uzimajući u obzir visok stupanj koncentracije i činjenicu da na banke iz uzorka otpada 80 \% tržišnog udjela, a one su najviše zaslužne za kontinuirano održavanje visokog udjela stranog vlasništva (preko $90 \%$ u imovini ukupnog bankovnog sektora. Konkretnije, u radu se analiziraju proces i razlozi smanjenja broja banaka, uloga velikih banaka u tome te izabrani računovodstveni pokazatelji profitabilnosti, efikasnosti i likvidnosti u tom kontekstu. Cilj navedene analize je utvrditi u kojoj su mjeri pravne, makroekonomske, financijske i ostale promjene utjecale na poslovanje velikih banaka u usporedbi s rezultatima ostvarenim na razini ukupnog bankovnog sektora.

Rad je podijeljen na pet dijelova. Nakon uvodnog prvog dijela, u drugom dijelu slijedi definiranje velikih banaka i pregled literature iz područja analize poslovanja i efikasnosti velikih banaka. U trećem dijelu bit će prikazan hrvatski bankovni sustav te uloga i položaj velikih banaka u njemu, dok u četvrtom dijelu slijedi analiza poslovanja i izabranih pokazatelja poslovanja velikih banaka u Hrvatskoj. Peti dio predstavlja zaključak.

\section{TEORIJSKI OSVRT I PREGLED LITERATURE}

Regulacija EU-a pod velike financijske institucije ubraja sve institucije s aktivom većom od 70 mlrd. EUR pojedinačno ili na konsolidiranoj osnovi (Regulation (EU) No. 575/2013 (CRR), čl. 142(1)(4)(a)). Kad se promatra bankovni sektor EU-a, velike banke obuhvaćaju sve banke s aktivom većom od 0,5\% ukupne aktive banaka EU-a na konsolidiranoj osnovi (tablica I). Za Republiku Hrvatsku učinjena je slična kategorizacija, ali uzimajući u obzir specifičnu strukturu, koncentraciju i veličinu aktive bankovnog sektora. 
Tablica I: Kategorizacija banaka prema veličini aktive: usporedba SAD-a, EU-a i RH

\begin{tabular}{|l|l|l|l|}
\hline & SAD & EU & $R H$ \\
\hline Veličina banke & U mlrd. USD & $U \%$ aktive banaka EU-a & U\% aktive banaka RH \\
\hline Velike & $>10$ mlrd. USD & $>0,5 \%$ & $>5 \%$ \\
\hline Srednje & $10>\mathrm{x}>1 \mathrm{mlrd}$. USD & $0,5 \%>\mathrm{X}>0,005 \%$ & $5 \%>\mathrm{X}>1 \%$ \\
\hline Male & $<1 \mathrm{mlrd}$. USD & $<0,005 \%$ & $<1 \%$ \\
\hline
\end{tabular}

Izvor: prema ECB (2021). Official data (dostupno na: https://www.ecb.europa.eu/stats/supervisory_prudential_ statistics/consolidated_banking_data/html/index.en.html) i Šverko, I., Pavlović, A., Vukas, J. (2012). Analiza poslovanja malih banaka u Republici Hrvatskoj. Privredna kretanja i ekonomska politika, Vol. 133, str. 29-30.

Za izračun financijskih pokazatelja poslovanja koriste se podatci iz temeljnih financijskih izvještaja: bilance stanja i računa dobiti i gubitka. Kod temeljnih financijskih pokazatelja poslovanja banaka najčešće se izračunavaju, prikazuju i analiziraju računovodstveni pokazatelji, a među njima pokazatelji profitabilnosti i efikasnosti. Velik broj istraživanja proveden je u području analize efikasnosti i profitabilnosti poslovanja banaka, kako na razini banaka i njihovih poslovnica ili podružnica, tako i na razini pojedinih bankovnih sektora, ali i specifičnije na uzorku banaka podijeljenih u skupine, primjerice po veličini aktive kroz podjelu na velike, srednje i male banke. Matematički pristup analizi efikasnosti banaka utvrđivanjem koeficijenata efikasnosti pomoću metode linearnog programiranja analizom omeđivanja podataka postao je jedan od popularnijih pristupa kao zamjena ili nadopuna računovodstvenom pristupu izračuna pokazatelja efikasnosti i profitabilnosti, pa je većina novijih znanstvenih istraživanja iz metodoloških razloga više orijentirana upravo na ovaj pristup analizi efikasnosti. S druge strane i zbog navedenih razloga, računovodstveni pristup je postao manje zastupljen u takvim istraživanjima unatoč uočenoj prednosti matematičkog pristupa kao nadopune, a ne kao zamjene računovodstvenoj analizi profitabilnosti i efikasnosti (Jurčević i Mihelja Žaja, 2013; Tuškan i Stojanović, 2016). Zbog navedenog, ovaj rad je usmjeren na računovodstveni pristup analizi izabranih pokazatelja poslovanja banaka, primarno pokazatelja profitabilnosti i efikasnosti.

S obzirom na prilagođenije poslovne modele (Novickyte i Droždz, 2018), specifičnost poslovanja, diverzificiraniju ponudu proizvoda i usluga, kanale distribucije, znanje i tehnologiju kojim raspolažu i geografsku disperziju (kako poslovnica na lokalnoj razini, tako i članica grupe kod međunarodnih bankovnih grupacija), često se pretpostavlja da velike banke lakše i češće ostvaruju bolje pokazatelje profitabilnosti i efikasnosti zbog ekonomije razmjera u odnosu na primjerice male banke koje su poslovanjem orijentirane lokalno, na uži segment klijenata i uz specifičniju ponudu proizvoda i usluga i njihovu distribuciju, i samim time neiskorištenu ekonomiju razmjera (Fries i Taci, 2005). Navedeno potvrđuju i neka istraživanja provedena u tom području, a koja obuhvaćaju jedan ili oba pristupa u analizi efikasnosti i/ili profitabilnosti, matematički i računovodstveni, te su prikazani u nastavku. Razina neefikasnosti je uobičajeno niža za velike banke u usporedbi s malim bankama, s obzirom na prijavljenu višu razinu čiste tehničke efikasnosti kod velikih banaka prema istraživanjima koje koriste matematički pristup analize omeđivanja podataka (Berger et al., 1993, Drake, 2001), a kao glavni razlog za to pronalaze u višem stupnju koncentracije i manjoj konkurenciji kod velikih banaka. Jemrić i Vujčić (2002) u svom istraživanju efikasnosti hrvatskog bankovnog sektora primjenom analize omeđivanja podataka zaključili su kako su manje banke globalno efikasne, dok su velike banke lokalno efikasne. Ipak, novija 
istraživanja ukazuju na manju efikasnost ili neefikasnost velikih banaka u odnosu na male banke ukoliko nemaju dobru poslovnu politiku: ako im depoziti zauzimaju značajan udio

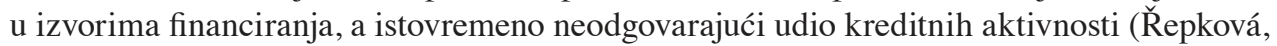
2014). Stoga, veličina banaka s obzirom na posebne karakteristike i specifičnost poslovanja velikih banaka u odnosu na male banke u specifičnom poslovnom okruženju može imati i negativan utjecaj na efikasnost, dok male banke mogu profitirati od ekonomija razmjera i obujma (potencijal rasta i širenja) samo do određene razine (Shawtari et al., 2018). Rezultati istraživanja efikasnosti bankovnih sektora Europske unije primjenom matematičkog i računovodstvenog pristupa ukazali su na manje, posttranzicijske i ostale bankovne sustave iz Jugoistočne Europe kao efikasnije u usporedbi s ostalim sektorima iz uzorka, s obzirom na specifičnost takvih bankovnih sustava (dominantna i jeftina depozitna osnova financiranja i s druge strane viša kamatna marža), a što je i jedan od glavnih razloga prisutnosti i širenja velikih međunarodnih bankovnih grupacija na tom području (Tuškan i Stojanović, 2016). Ipak, računovodstveni pokazatelji efikasnosti i profitabilnosti «kasnili» su u odnosu prema rezultatima efikasnosti primjenom analize omeđivanja podataka, pa se matematički pristup sugerira kao poželjna nadopuna u analizi efikasnosti poslovanja banaka i pravodobnom otkrivanju naznaka kriza ili drugih anomalija u poslovnom okruženju, a što je važno za manje bankovne sustave koji se uglavnom teže mogu prilagoditi takvim okolnostima i odgovoriti na stres (Tuškan i Stojanović, 2016). Zaključno, ipak je više istraživanja koja potvrđuju veću efikasnost malih banaka (bankovnih sustava) u odnosu prema velikim bankama (bankovnim sustavima). U Republici Hrvatskoj pak, efikasne male banke ostvaruju nešto višu efikasnost u usporedbi sa svim efikasnim bankama na razini cjelokupnog bankovnog sektora, najčešće zbog agresivnije poslovne politike malih banaka, no nema značajnijih razlika u razini i trendu prosječne efikasnosti u oba segmenta (Tuškan Sjauš, 2020). Rezultati analize Tuškan Sjauš i Mihelja Žaja (2020) ukazali su na značajnije negativne učinke financijske krize i recesije na broj banaka uslijed naglašenijeg trenda njihova propadanja i okrupnjavanja, te na pokazatelje efikasnosti u razdoblju 2013. - 2016. godine, a koji su rezultat pogoršanja stanja u dijelu troškova i prihoda uključenih u analizu omeđivanja podataka kao inputa i outputa. Zbog navedenog, dodatno se usporedno analiziraju i uzimaju u obzir za donošenje potpunijih zaključaka o efikasnosti i profitabilnosti upravo izabrani računovodstveni pokazatelji.

\section{POLOŽAJ VELIKIH BANAKA U BANKOVNOM SEKTORU}

\subsection{Stanje u bankovnom sektoru, kretanje broja i veličine banaka u Europskoj uniji}

Aktiva banaka u Europskoj uniji krajem 2019. godine dosegla je vrijednost od 49.300 mlrd. EUR, a pokazatelj ROE bio je na razini 5,4 \% (EBF, 2020). S obzirom na zamjetniji trend okrupnjavanja, ali i propadanja banaka nakon izbijanja financijske krize 2008. godine, na razini Europske unije broj kreditnih institucija se od 2008. godine smanjio čak za trećinu, s 8.525 u 2008. godini na 5.981 u 2019. godini (EBF, 2020). Koncentracija broja banaka, promatrana po zemljama, naglašena je s obzirom na to da je prema podacima za 2019. godinu u Njemačkoj, Poljskoj, Austriji, Italiji, Francuskoj i Španjolskoj poslovalo gotovo tri četvrtine od ukupnog broja kreditnih institucija u EU-u (grafikon I). 
Grafikon I: Vodeći bankovni sustavi u EU-u prema broju kreditnih institucija, udjeli u \%, 2019. godina

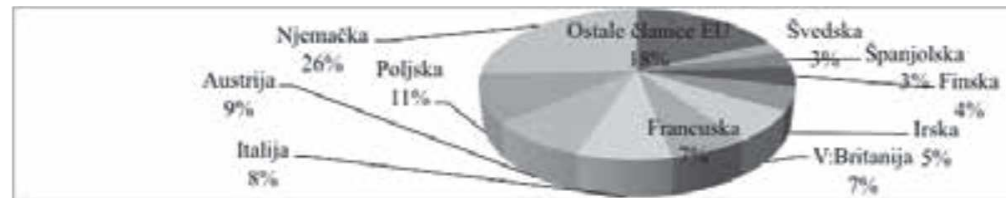

Izvor: EBF (2020). Facts \& Figures 2019

Promatrano po zemljama i prema veličini aktive, tri bankovna sektora - francuski kao najveći (7,400 mlrd. EUR), britanski i njemački, imala su udio veći od $50 \%$ u ukupnoj aktivi bankovnog sektora EU-a krajem 2019. godine (EBF, 2020).

Među deset najvećih bankovnih grupa prema veličini aktive sa sjedištem u Europskoj uniji krajem 2019. godine bile su tri banke sa sjedištem u UK-u (HSBC Holdings bila je na prvom mjestu s aktivom većom od 2.400 mlrd. EUR), četiri iz Francuske, te po jedna iz Njemačke, Španjolske i Nizozemske (grafikon II).

Grafikon II: Vodeće banke sa sjedištem u EU-u prema veličini aktive, u mlrd. EUR, 2019. godina

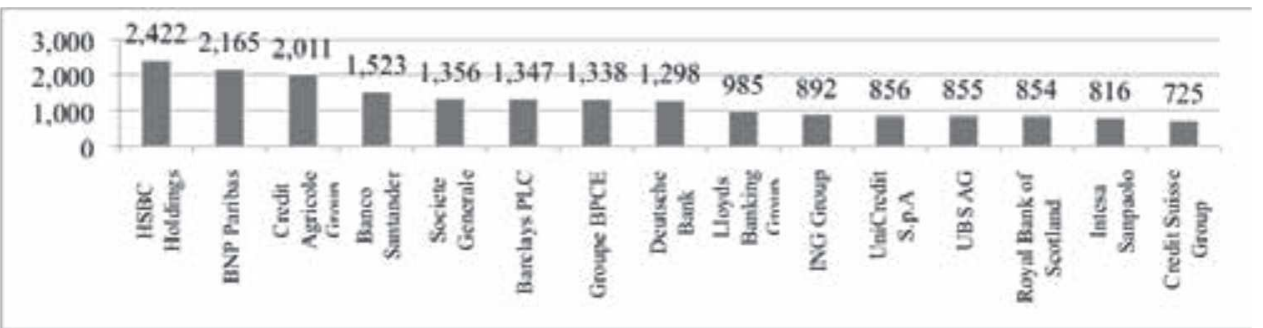

Izvor: Izrada autora prema Statista (2020). Statistical data. (dostupno na: https://www.statista.com/statistics/383406/leading-europe-banks-by-total-assets/)

Velike međunarodne bankovne grupacije prisutne u Republici Hrvatskoj i ostalim zemljama regije Jugoistočne Europe značajno su promijenile poslovnu politiku u postkriznom razdoblju s obzirom na višu izloženost rizicima i ostale učinke krize na financijski sektor i ekonomiju na tim područjima. Neke od njih smanjile su svoje tržišne udjele u toj regiji dok su druge iskoristile priliku za bolje tržišno pozicioniranje kroz poduzimanje aktivnosti okrupnjavanja i tako povećale svoju imovinu. Uloga velikih međunarodnih bankovnih grupacija značajno je naglašena u Hrvatskoj s obzirom na visok udio stranog vlasništva u ukupnoj aktivi bankovnog sektora, a koncentrirano upravo kod vodećih banaka po veličini.

\subsection{Promjene i stanja izabranih pokazatelja poslovanja banaka u Republici Hrvatskoj od 2012. do 2019. godine - osvrt na položaj velikih banaka}

U regiji Jugoistočne Europe krajem 2019. godine među deset najvećih banaka prema veličini aktive bile su dvije hrvatske banke: Zagrebačka banka i Privredna banka, (See- 
News, 2020), a koje i u hrvatskom bankovnom sektoru imaju dominantnu ulogu ukoliko se promatra indeks koncentracije: dvije najveće banke zauzimale su gotovo $50 \%$, četiri najveće banke gotovo $75 \%$, a na pet najvećih banaka koje čine uzorak u ovoj analizi odnosi se čak $80 \%$ aktive ukupnog bankovnog sektora Republike Hrvatske prema podacima za 2019. godinu (tablica II). Cilj je ovog rada prikazati rezultate analize poslovanja velikih banaka u Republici Hrvatskoj, no s obzirom na kontinuirani rast i značajan udio aktive velikih banaka u ukupnoj aktivi bankovnog sektora i posljedični utjecaj kretanja u skupini velikih banaka na kretanja u ukupnom bankovnom sektoru, u nastavku (tablica II) su prikazani izabrani agregirani pokazatelji poslovanja na razini cijelog hrvatskog bankovnog sektora izračunati na temelju podataka iz temeljnih financijskih izvještaja. Pokazatelji rizičnosti, profitabilnosti i efikasnosti pod utjecajem brojnih strukturnih promjena varirali su kako na razini pojedinih banaka tako i na razini ukupnog bankovnog sektora čije su se vrijednosti tek od 2017. godine uglavnom vratile na razine ostvarivane u pretkriznom razdoblju (pokazatelji profitabilnosti već u 2016. godini).

Tablica II: Izabrani pokazatelji poslovanja banaka u Republici Hrvatskoj, 2012. - 2019.

\begin{tabular}{|l|c|c|c|c|c|c|c|c|}
\hline & 2012. & 2013. & 2014. & 2015. & 2016. & 2017. & 2018. & 2019. \\
\hline Broj banaka & 31 & 30 & 28 & 28 & 26 & 25 & 21 & 20 \\
\hline $\begin{array}{l}\text { Broj velikih banaka (udio aktive } \\
>5 \% \text { uk. aktive) }\end{array}$ & 6 & 6 & 6 & 6 & 6 & 6 & 6 & 6 \\
\hline $\begin{array}{l}\text { Prinos na prosječnu imovinu } \\
\text { (ROAA), \% }\end{array}$ & 0,8 & 0,2 & 0,5 & $-1,3$ & 1,6 & 1,0 & 1,4 & 1,6 \\
\hline $\begin{array}{l}\text { Prinos na prosječni kapital } \\
\text { (ROAE), \% }\end{array}$ & 4,8 & 0,8 & 2,8 & $-8,8$ & 9,6 & 5,9 & 8,5 & 9,9 \\
\hline $\begin{array}{l}\text { Financijska poluga (kapital / } \\
\text { ukupna imovina), \% }\end{array}$ & 14,0 & 14,1 & 14,0 & 13,4 & 13,4 & 14,5 & 14,4 & 14,0 \\
\hline $\begin{array}{l}\text { Kamatni prihodi / prosječna } \\
\text { kamatna imovina, \% }\end{array}$ & - & - & - & 4,4 & 4,1 & 3,7 & 3,0 & 3,0 \\
\hline $\begin{array}{l}\text { Kamatni troškovi / prosječne } \\
\text { kamatne obveze, \% }\end{array}$ & - & - & - & 1,8 & 1,3 & 0,8 & 0,5 & 0,4 \\
\hline $\begin{array}{l}\text { Troškovna efikasnost (CIR, opći } \\
\text { troškovi poslovanja / operativni } \\
\text { prihod), \% }\end{array}$ & 51,8 & 52,0 & 51,3 & 51,7 & 45,0 & 46,7 & 47,8 & 46,8 \\
\hline $\begin{array}{l}\text { Neto kamatna marža (NIM, } \\
\text { neto kamatni prihod / prosječna } \\
\text { aktiva), \% }\end{array}$ & 2,7 & 2,5 & 2,6 & 2,7 & 2,8 & 2,8 & 2,4 & $\mathrm{n} / \mathrm{a}$ \\
\hline $\begin{array}{l}\text { Kamatna razlika (IRS, kmt. } \\
\text { prihod / prosječ. kmt. aktiva- } \\
\text { kmt.trošak / prosječ. kmt. } \\
\text { obveze), \% }\end{array}$ & 2,3 & 2,3 & 2,5 & 2,6 & 2,8 & 2,9 & 2,5 & 2,6 \\
\hline $\begin{array}{l}\text { Omjer zajmova i depozita } \\
\text { (LDR), \% }\end{array}$ & 98,3 & 93,3 & 88,5 & 83,9 & 79,9 & 76,1 & 80,0 & $\mathrm{n} / \mathrm{a}$ \\
\hline
\end{tabular}




\begin{tabular}{|l|c|c|c|c|c|c|c|c|}
\hline & 2012. & 2013. & 2014 & 2015. & 2016. & 2017. & 2018. & 2019. \\
\hline $\begin{array}{l}\text { Indeks koncentracije: udio } \\
\text { imovine 2 najveće banke u } \\
\text { ukupnoj imovini, \% }\end{array}$ & 43,3 & 43,4 & 43,5 & 44,7 & 45,7 & 45,5 & 48,0 & 48,3 \\
\hline $\begin{array}{l}\text { Indeks koncentracije: udio } \\
\text { imovine 4 najveće banke u } \\
\text { ukupnoj imovini, \% }\end{array}$ & 66,9 & 66,8 & 66,6 & 67,6 & 68,2 & 68,1 & 73,4 & 73,5 \\
\hline $\begin{array}{l}\text { Indeks koncentracije: udio } \\
\text { imovine 5 najvećih banaka u } \\
\text { ukupnoj imovini, \% }\end{array}$ & 74,0 & 73,0 & 72,0 & 73,0 & 74,0 & 74,0 & 80,0 & 81,0 \\
\hline $\begin{array}{l}\text { Neprihodujući krediti u uk. } \\
\text { kreditima (NPL), \% }\end{array}$ & 13,9 & 15,7 & 17,1 & 16,7 & 12,1 & 8,73 & 7,49 & 5,47 \\
\hline $\begin{array}{l}\text { Stopa ukupnog kapitala } \\
\text { (TCR), \% }\end{array}$ & 20,9 & 21,0 & 21,8 & 20,9 & 22,9 & 23,8 & 23,1 & 24,8 \\
\hline Stopa promjene imovine, \% & $-1,7$ & $-0,5$ & $-0,7$ & $-0,5$ & $-1,2$ & 0,7 & 4,4 & 4,19 \\
\hline Ukupna imovina, mlrd. HRK & 399,9 & 397,9 & 395,2 & 393,4 & 388,7 & 391,3 & 408,7 & 425,8 \\
\hline Dobit prije poreza, mlrd. HRK & 3,4 & 0,7 & 2,1 & $-5,0$ & 6,2 & 3,9 & 5,6 & 6,6 \\
\hline Neto dobit, mlrd. HRK & 2,7 & 0,5 & 1,5 & $-4,6$ & 5,0 & 3,4 & 4,9 & 5,4 \\
\hline
\end{tabular}

Izvor: izrada autora prema HNB, Statistički podaci, Standardni prezentacijski format i Bilteni o bankama (različita izdanja)

Općenito promatrano, razdoblje nakon 2012. godine u bankovnom sektoru obilježilo je ,čišćenje“ aktive od loših plasmana, dokapitalizacija, te pad prihoda i dobiti većine banaka na tržištu. U tom razdoblju provedeno je pet pripajanja među bankama uz jedno pripajanje od strane inozemne matične banke čime je predmetna banka u Hrvatskoj postala podružnica, te dva pripajanja stambenih štedionica od strane banaka. Dodatno, pet banaka je promijenilo ime u postupcima stjecanja, odnosno promjene vlasništva, nad tri banke je pokrenut postupak likvidacije ili stečajni postupak, a dvjema bankama je oduzeto i odobrenje za rad (tablica III).

Dakle, kroz promatrani period, od 2012. do 2019. godine, zamjetni su različiti trendovi u kretanju izabranih pokazatelja poslovanja, a smanjenje broja banaka za trećinu i izraženiji porast ionako visokog indeksa koncentracije banaka uslijed procesa stjecanja, spajanja i pripajanja te stečajni postupci otvoreni nad nekoliko manjih banaka neki su od najzamjetnijih (tablica III). Sve navedeno dodatno je naglasilo tržišnu dominaciju nekolicine najvećih banaka, članica ili podružnica velikih međunarodnih bankovnih grupacija, jer upravo su najveće banke u Republici Hrvatskoj, koje su dio velikih međunarodnih bankovnih grupa, imale važnu ulogu u spomenutim procesima okrupnjavanja. Najznačajnije pripajanje po veličini odnosi se na pripajanje Splitske banke OTP banci u 2018. godini. Tim pripajanjem OTP banka Hrvatska postala je jedna od pet najvećih banaka u Republici Hrvatskoj te zauzela četvrto mjesto po svojoj veličini u bankovnom sustavu. Najveći rast koncentracije se, stoga, dogodio u 2018. godini, a iste godine je Privrednoj banci Zagreb pripojena Veneto banka. Udio stranog vlasništva tako je i dalje zadržan na razinama preko $90 \%$. (HNB, 2020) 
Tablica III: Pregled promjena vlasništva, okrupnjavanja i propadanja banaka te ostalih povezanih promjena u hrvatskom bankovnom sektoru, 2012. - 2019.

\begin{tabular}{|c|c|}
\hline 2012. & $\begin{array}{l}\text { Međimurska banka d. d. pripojena je 30. studenog 2012. Privrednoj banci Zagreb } \\
\text { d. d. }\end{array}$ \\
\hline \multirow[t]{2}{*}{2013.} & Volksbank d. d. promijenila je 18. siječnja 2013. ime u Sberbank d. d. \\
\hline & Nad Centar bankom d. d. Zagreb pokrenut je stečajni postupak 30. rujna 2013. \\
\hline \multirow[t]{2}{*}{2014.} & $\begin{array}{l}\text { Banco Popolare Croatia d. d. pripojena je 1. prosinca 2014. OTP banci Hrvatska } \\
\text { d. d. }\end{array}$ \\
\hline & Nad Nava bankom d. d. Zagreb pokrenut je stečajni postupak 1. prosinca 2014. \\
\hline \multirow[t]{3}{*}{2016.} & $\begin{array}{l}\text { Nad Bankom splitsko-dalmatinskom d. d., 1.lipnja 2016. otvoren je stečajni } \\
\text { postupak . }\end{array}$ \\
\hline & $\begin{array}{l}\text { Hypo Alpe-Adria-Bank d. d., Zagreb, promijenila je 11. srpnja 2016. ime u } \\
\text { Addiko Bank d. d., Zagreb. }\end{array}$ \\
\hline & $\begin{array}{l}\text { BKS Bank d. d., Rijeka pripojena je BKS Bank AG, Klagenfurt 1. listopada } \\
\text { 2016, a poslovanje u Hrvatskoj od 30. lipnja 2017. godine nastavlja pod imenom } \\
\text { BKS Bank AG, Podružnica Hrvatska, }\end{array}$ \\
\hline \multirow[t]{3}{*}{2017.} & $\begin{array}{l}\text { Vaba d. d. banka Varaždin, Varaždin, promijenila je 2. siječnja 2017. ime u J\&T } \\
\text { banka d. d., Varaždin. }\end{array}$ \\
\hline & $\begin{array}{l}\text { Société Générale-Splitska banka d. d., Split, promijenila je 15. svibnja 2017. ime } \\
\text { u Splitska banka d. d., Split. }\end{array}$ \\
\hline & Štedbanka d. d., Zagreb pokrenula postupak likvidacije 27. prosinca 2017. \\
\hline \multirow[t]{5}{*}{2018.} & Primorska banka d. d., Rijeka pokrenula je postupak likvidacije 21. lipnja 2018. \\
\hline & $\begin{array}{l}\text { Kreditna banka Zagreb d. d. promijenila je 28. prosinca 2018. ime u Agram } \\
\text { banka d .d. }\end{array}$ \\
\hline & Veneto banka d. d. pripojena je 12. listopada 2018. Privrednoj banci Zagreb d. d. \\
\hline & Prva stambena štedionica d. d. pripojena je 1. lipnja 2018. Zagrebačkoj banci d. d. \\
\hline & $\begin{array}{l}\text { Splitska banka d. d. pripojena je 3. prosinca 2018. OTP banci Hrvatska d. d. koja } \\
\text { tada seli sjedište iz Zadra u Split. }\end{array}$ \\
\hline \multirow[t]{2}{*}{2019.} & $\begin{array}{l}\text { Dana 1. travnja 2019. Jadranska banka je pripojena Hrvatskoj poštanskoj banci } \\
\text { d. d, (Postupak sanacije Jadranske banke d. d Šibenik započet je 9. listopada } \\
\text { 2015., a okončan je 13. srpnja 2018.) }\end{array}$ \\
\hline & HPB-Stambena štedionica d. d. pripojena je 2. prosinca 2019. Hrvatskoj \\
\hline
\end{tabular}

Izvor: izrada autora prema HNB (2012-2020), Statistički podaci.

Okrupnjavanje i propadanje banaka koje je rezultiralo smanjenjem broja banaka izravna je posljedica financijske krize koja je utjecala na poslovanje banaka i opstanak stabilnih banaka koje su se uspješno prilagodile novonastalim okolnostima. Općenito, najveći dio razdoblja od 2012. do 2019. godine obilježen je brojnim promjenama u političkom, financijskom i makroekonomskom okruženju, a regulatorne promjene uslijed pristupanja Republike Hrvatske Europskoj uniji 2013. godine dodatno su utjecale na prilagodbu poslovne politike banaka. Značajan utjecaj na kretanja izabranih pokazatelja bankovnog poslovanja imali su učinci financijske krize i njezino prelijevanje na ekonomiju, koje se negativno 
odrazilo na makroekonomske pokazatelje i smanjenje kreditne aktivnosti banaka, a što je rezultiralo produženim razdobljem recesije, sve do 2015. godine.

Postroženi kreditni uvjeti, rast djelomično nadoknadivih i potpuno nenadoknadivih kredita, visoka likvidnost i visok udio neuposlenih sredstava (smanjenje omjera kredita i depozita) ostavili su značajne posljedice na pokazatelje profitabilnosti i efikasnosti poslovanja banaka, ali i pokazatelje rizičnosti. Dodatno su i odluka o konverziji kredita indeksiranih u švicarskim francima u kredite indeksirane u eurima 2015. godine te posljedice izloženosti pojedinih banaka prema Agrokor grupi uslijed zbivanja tijekom 2018. godine utjecale na poslovne rezultate banaka. Trošak konverzije utjecao je na ostvarenje gubitaka kod gotovo svih banaka u 2015. godini, te su na razini bankovnog sektora ostvareni najlošiji rezultati poslovanja u odnosu na preostalo promatrano razdoblje (tablica II). Konačno, i poteškoće u poslovanju grupe Agrokor uzrokovale su velike troškove ispravaka vrijednosti i rezerviranja, koji su dodatno opteretili profitabilnost banaka. Ipak, osim takvih negativnih izvanrednih događaja, bilo je i pozitivnih aktivnosti: prodaja udjela u Visa Europe LTD-u te udjela povezanih društava utjecala je na dodatnu zaradu na razini bankovnog sektora 2016. godine, što je sa stabilizacijom ostalih financijskih i makroekonomskih čimbenika rezultiralo najvišom razinom pokazatelja profitabilnosti prosječne imovine i profitabilnosti prosječnog kapitala u odnosu na promatrano razdoblje do tada, te njihovim daljnjim oporavkom. (HNB, 2012-2020)

Prema tablici II, pokazatelji profitabilnosti prinos na prosječnu imovinu (engl. Return on Average Assets, ROAA) i prinos na prosječni kapital (engl. Return on Average Equity, ROAE) u razdoblju od 2012. do 2015. godine bilježili su izraženiji pad vrijednosti zbog narušene kvalitete aktive uslijed rasta udjela u potpunosti ili djelomično nenadoknadivih kredita (engl. Non-Perfoming Loans, NPL) koji je do 2012. porastao na $14 \%$ s vrhuncem u 2014. godini (preko $17 \%$ ), a koji je posljedično uzrokovao povećanje troškova ispravaka vrijednosti i značajnijeg pada dobiti. Dodatno i pokazatelj troškovne efikasnosti (engl. Cost-to-Income Ratio, CIR), svojim porastom potvrđuje pad uspješnosti poslovanja banaka u promatranom razdoblju. Dovršetkom procesa čišćenja aktive od loših kredita, i nakon konverzije stambenih kredita indeksiranih u švicarskim francima u kredite u eurima ostvarili su se uvjeti za stabilizaciju poslovanja koja se odrazila i na ponovni rast dobiti te vraćanje pokazatelja profitabilnosti i efikasnosti u razdoblju nakon 2016. godine na prihvatljivije razine. S druge strane, kamatna razlika (engl. Interest Rate Spread, IRS) i neto kamatna marža (engl. Net-Interest-Margin, NIM) imale su određene oscilacije u trendu kretanja u promatranom razdoblju ovisno o tome jesu li zabilježene veće uštede na kamatnim troškovima ili su više padali kamatni prihodi. Na manji pad neto kamatne marže najviše je djelovalo smanjenje kamatnih stopa, dodatno i zbog pristupanja Republike Hrvatske Europskoj uniji, ali isto tako i rast udjela nenaplativih kredita koji je utjecao na smanjenje kamatnih prihoda. Omjer zajmova i depozita (engl. Loan-to-Deposit Ratio, LDR), čiji bi idealan omjer bio između $80 \%$ i $90 \%$, u padu je pak čitavo promatrano razdoblje, najviše zbog pada kreditne aktivnosti sve do 2017. godine, ali i čišćenja aktive od nenaplativih kredita u promatranom razdoblju i ispravaka vrijednosti zbog izvanrednih događaja, a primarno konverzije kredita indeksiranih u švicarskim francima.

Trendovi pada kamatnih stopa, pad kreditne aktivnosti i čišćenje bilanci od loših kredita s jedne strane, te izvanredni događaji vezani uz konverziju stambenih kredita indeksiranih u švicarskim francima u kredite u eurima i poteškoće u poslovanju grupe 
Agrokor s druge strane, pored svih ostalih specifičnih makroekonomskih, financijskih i regulatornih događaja i promjena u poslovnom okruženju, značajno i dominantno su utjecali na analizirane promjene u hrvatskom bankovnom sustavu od 2012. do 2019. godine. S obzirom na to da je većina imovine hrvatskog bankovnog sektora u vlasništvu velikih banaka (pet banaka iz uzorka za analizu koja slijedi drži $80 \%$ imovine ukupnog bankovnog sustava), trendovi i stanja u bankovnom sektoru primarno su određeni upravo poslovanjem najvećih banaka koje su u fokusu ovog rada. U nastavku slijedi detaljnija analiza njihova poslovanja.

\section{ANALIZA POSLOVANJA VELIKIH BANAKA U HRVATSKOJ}

\subsection{Metodologija i podaci}

Deskriptivno-statistička analiza i komparativna analiza za potrebe istraživanja provedene su na dostupnim statističkim podacima koje objavljuje Hrvatska narodna banka, na uzorku pet hrvatskih banaka koje su ulazile u kategoriju velikih banaka u čitavom razdoblju od 2012. do 2019. godine. Za potrebe analize izdvojeni su i statistički obrađeni te usporedno prikazani podaci poslovanja čitavog hrvatskog bankovnog sektora za promatrani period.

Premda je na godišnjoj razini poslovalo šest velikih banaka (tablica IV), banke koje su u čitavom promatranom razdoblju poslovale i bile u kategoriji velikih privatnih su redom banke koje su dio velikih međunarodnih bankovnih grupacija: Zagrebačka banka (članica Grupe UniCredit), Privredna banka Zagreb (članica Grupe Intesa SanPaolo), Erste\&Steiermärkische Bank (članica Erste Group Bank), Société Générale-Splitska banka d. d./Splitska banka d. d. (od 2018. OTP banka, članica OTP Group) i Raiffeisenbank Austria (članica Grupe Raiffeisenbank International). OTP banka je uključena u uzorak za analizu s obzirom na to da je na specifičan način postala velika banka 2018. godine nakon strateškog pripajanja (veće) Splitske banke, a u analizu su usporedno uključeni i podaci za Splitsku banku za razdoblje do tada, s obzirom na to da je prema udjelu aktive ulazila u kategoriju velikih banaka u promatranom razdoblju do pripajanja (tablica IV). Addiko Bank je od 2019. godine postala banka srednje veličine s obzirom na trend značajnijeg smanjenja tržišnog udjela nakon preuzimanja problematične Hypo-Alpe-Adria banke koja se dugo borila s kvalitetom kreditnog portfelja, stoga je isključena iz uzorka, kao i Hrvatska poštanska banka koja je pak isključena iz analize s obzirom na to da je riječ o banci u domaćem državnom vlasništvu i koja je tek od 2018. godine u kategoriji velike banke. 
Tablica IV: Velike banke u Republici Hrvatskoj, 2012. - 2019., udjeli imovine u ukupnoj imovini, u \%

\begin{tabular}{|l|r|r|r|r|r|r|r|r|}
\hline & 2012. & 2013. & 2014. & 2015. & 2016. & 2017. & 2018. & 2019. \\
\hline $\begin{array}{l}\text { Addiko Bank d. d., Zagreb } \\
\text { (Hypo banka) }\end{array}$ & $\underline{8,52}$ & $\underline{7,41}$ & $\underline{7.01}$ & $\underline{6,37}$ & $\underline{5,32}$ & $\underline{5,31}$ & 4,44 & 4,17 \\
\hline $\begin{array}{l}\text { Erste\&Steiermärkische } \\
\text { Bank d .d., Rijeka }\end{array}$ & $\underline{14,41}$ & $\underline{14,83}$ & $\underline{14,93}$ & $\underline{14,71}$ & $\underline{14,15}$ & $\underline{14,33}$ & $\underline{14,84}$ & $\underline{14,83}$ \\
\hline $\begin{array}{l}\text { Hrvatska poštanska banka } \\
\text { d. d., Zagreb }\end{array}$ & 4,19 & 4,53 & 4,31 & 4,42 & 4,88 & 4,96 & $\underline{5,13}$ & $\underline{5,53}$ \\
\hline OTP banka d.d., Split & 3,28 & 3,39 & 3,94 & 3,96 & 3,98 & 4,92 & $\underline{10,18}$ & $\underline{10,22}$ \\
\hline $\begin{array}{l}\text { Privredna banka Zagreb d. } \\
\text { d., Zagreb }\end{array}$ & $\underline{16,93}$ & $\underline{16,24}$ & $\underline{17,15}$ & $\underline{17,38}$ & $\underline{18,27}$ & $\underline{19,01}$ & $\underline{20,05}$ & $\underline{20,30}$ \\
\hline $\begin{array}{l}\text { Raiffeisenbank Austria d. } \\
\text { d., Zagreb }\end{array}$ & $\underline{8,76}$ & $\underline{8,14}$ & $\underline{7,80}$ & $\underline{7,78}$ & $\underline{7,92}$ & $\underline{7,86}$ & $\underline{7,88}$ & $\underline{7,90}$ \\
\hline $\begin{array}{l}\text { Splitska banka d. d., Split } \\
\text { (Société Générale-Splitska } \\
\text { banka d. d.) }\end{array}$ & $\underline{6,49}$ & $\underline{6,74}$ & $\underline{7,14}$ & $\underline{6,75}$ & $\underline{6,82}$ & $\underline{6,74}$ & - & - \\
\hline $\begin{array}{l}\text { Zagrebačka banka d. d., } \\
\text { Zagreb }\end{array}$ & $\underline{25,56}$ & $\underline{26,36}$ & $\underline{25,43}$ & $\underline{26,42}$ & $\underline{26,51}$ & $\underline{25,59}$ & $\underline{27,35}$ & $\underline{27,29}$ \\
\hline
\end{tabular}

Izvor: izrada autora prema HNB (2012-2020), Statistički podaci.

Pokazatelji poslovanja banaka iz uzorka koji su uključeni u analizu su računovodstveni pokazatelji profitabilnosti: prinos na imovinu (engl. Return on Assets, ROA) i prinos na kapital (engl. Return on Equity, ROE), pokazatelji efikasnosti: troškovna efikasnost (engl. Cost-to-Income Ratio, CIR) i neto kamatna marža (engl. Net Interest Margin, NIM), te omjer zajmova i depozita (engl. Loan-to-Deposit Ratio, LDR) kao jednostavan pokazatelj likvidnosti.

Prinos na imovinu (ROA) izračunava se kao omjer dobiti ili (-) gubitka (neto) tekuće godine (na godišnjoj razini) i prosječne imovine kreditnih institucija. Prosječna imovina izračunava se kao aritmetička sredina iznosa imovine na kraju izvještajnog razdoblja i iznosa imovine na kraju prethodne godine. Prinos na kapital (ROE) izračunava se kao omjer dobiti ili (-) gubitka (neto) tekuće godine (na godišnjoj razini) i prosječnoga kapitala kreditnih institucija. Prosječan kapital izračunava se kao aritmetička sredina iznosa kapitala na kraju izvještajnog razdoblja i iznosa kapitala na kraju prethodne godine. Pokazatelj troškovne efikasnosti (CIR) izračunava se kao omjer općih troškova poslovanja (opći administrativni troškovi i amortizacija) i ukupnoga prihoda iz poslovanja (neto). Neto kamatna marža (NIM) predstavlja omjer neto kamatnog prihoda i imovine banke koja donosi zaradu, pri čemu se neto kamatni prihod izračunava kao razlika između kamatnih prihoda banke (zarađene kamate od odobrenih kredita) i kamatnih rashoda (plaćene kamate na prikupljene depozite). Omjer zajmova i depozita (LDR) izračunava se kao odnos odobrenih kredita i depozita u izvorima sredstava. (Žager et al., 2009; HNB, 2021) 


\subsection{Rezultati istraživanja}

U nastavku su izloženi nalazi provedene analize osnovnih pokazatelja profitabilnosti, efikasnosti i likvidnosti u razdoblju od 2015. do 2019. godine za odabranih pet velikih banaka. U tom smislu prikazane su godišnje razine i prosjeci pokazatelja na razini pojedinih banaka za čitavo promatrano razdoblje, te su označene minimalne i maksimalne vrijednosti pokazatelja. Rezultati su prikazani usporedno s rezultatima za cijeli bankovni sektor za potrebe donošenja konkretnijih zaključaka o uspješnosti poslovanja velikih banaka u Republici Hrvatskoj.

Naredne dvije tablice prikazuju razine osnovnih pokazatelja profitabilnosti: prinosa na imovinu (tablica V) i prinosa na kapital (tablica VI).

Tablica V: Prinos na imovinu (ROA) pet najvećih banaka u Republici Hrvatskoj i prosjek hrvatskog bankovnog sustava, 2012. - 2019.

\begin{tabular}{|c|c|c|c|c|c|c|c|c|c|}
\hline & 2012. & 2013. & 2014. & 2015. & 2016. & 2017. & 2018. & 2019. & Prosjek \\
\hline Zagrebačka banka & $0,86 \%$ & $0,44 \%$ & $1,14 \%$ & $-0,49 \%$ & $1,63 \%$ & $0,82 \%$ & $1,64 \%$ & $1,33 \%$ & $0,92 \%$ \\
\hline $\begin{array}{l}\text { Privredna banka } \\
\text { Zagreb }\end{array}$ & $1,24 \%$ & $0,94 \%$ & $0,93 \%$ & $0,28 \%$ & $\begin{array}{l}2,23 \% \\
(\mathrm{MAX})\end{array}$ & $1,91 \%$ & $1,66 \%$ & $2,15 \%$ & $1,42 \%$ \\
\hline $\begin{array}{l}\text { Raiffeisenbank } \\
\text { Austria }\end{array}$ & $1,02 \%$ & $0,84 \%$ & $0,94 \%$ & $-0,77 \%$ & $1,46 \%$ & $1,26 \%$ & $0,67 \%$ & $1,29 \%$ & $0,84 \%$ \\
\hline $\begin{array}{l}\text { Erste\&Steiermär- } \\
\text { kische Bank }\end{array}$ & $0,83 \%$ & $0,11 \%$ & $0,39 \%$ & $\begin{array}{r}-1,72 \% \\
(\mathrm{MIN}) \\
\end{array}$ & $1,12 \%$ & $1,13 \%$ & $1,35 \%$ & $1,18 \%$ & $0,55 \%$ \\
\hline $\begin{array}{l}\text { OTP banka } \\
\text { (Société Générale- } \\
\text { Splitska banka/ } \\
\text { Splitska banka) }\end{array}$ & $\begin{array}{l}0,75 \% \\
0,36 \%\end{array}$ & $\begin{array}{l}0,47 \% \\
0,12 \%\end{array}$ & $\begin{array}{l}0,98 \% \\
0,66 \%\end{array}$ & $\begin{array}{r}-0,50 \% \\
0,45 \%\end{array}$ & $\begin{array}{l}0,78 \% \\
1,35 \%\end{array}$ & $\begin{array}{r}0,27 \% \\
-0,32 \%\end{array}$ & $0,39 \%$ & $1,32 \%$ & $0,56 \%$ \\
\hline $\begin{array}{l}\text { RH bankovni } \\
\text { sustav - prosjek }\end{array}$ & $0,84 \%$ & $0,17 \%$ & $0,52 \%$ & $-1,28 \%$ & $1,58 \%$ & $1,00 \%$ & $1,40 \%$ & $1,58 \%$ & $0,73 \%$ \\
\hline
\end{tabular}

Izvor: HNB (2012-2020), Statistički podaci i Izabrane banke (2012-2019), Financijski izvještaji.

U razdoblju od 2012. do 2019. godine kretanje razine osnovnih pokazatelja profitabilnosti, prinosa na imovinu (tablica V) i prinosa na kapital (tablica VI), među svim promatranim velikim bankama, ali i u odnosu na prosjek cijelog bankovnog sektora, ukazuju na Privrednu banku Zagreb kao vodeću prema ostvarenim razinama profitabilnosti uz maksimume ostvarene 2016. godine (ROA) odnosno 2019. godine (ROE), a Privredna banka Zagreb je i 2015. godine ostvarila dobit te imala pozitivne vrijednosti pokazatelja u usporedbi s ostalim velikim bankama koje su pretrpjele gubitke i bilježile negativne vrijednosti pokazatelja profitabilnosti uslijed posljedica izloženosti i konverzije kredita indeksiranih u švicarskim francima u kredite u eurima. Najniže vrijednosti pokazatelja profitabilnosti ostvarila je Erste\&Steiermärkische Bank i to upravo u 2015. godini iz navedenih razloga. Općenito promatrano, Erste\&Steiermärkische Bank i OTP banka na godišnjoj su razini ostvarivale najlošije vrijednosti pokazatelja ROA pojedinačno te uglavnom niže i u usporedbi s prosjekom ukupnog bankovnog sektora, što je u konačnici dovelo do najnižih prosječnih vrijednosti za čitav promatrani period. Erste\&Steiermärkische Bank je ostvarila i najnižu prosječnu vrijednost pokazatelja ROE u odnosu na prosjek cijelog bankovnog sektora. 
Tablica VI: Prinos na kapital (ROE) pet najvećih banaka u Republici Hrvatskoj i prosjek hrvatskog bankovnog sustava, 2012. - 2019.

\begin{tabular}{|c|c|c|c|c|c|c|c|c|c|}
\hline & 2012. & 2013. & 2014. & 2015. & 2016. & 2017. & 2018. & 2019. & Prosjek \\
\hline Zagrebačka banka & $5,63 \%$ & $2,97 \%$ & $7,11 \%$ & $-3,51 \%$ & $10,37 \%$ & $5,34 \%$ & $11,31 \%$ & $9,47 \%$ & $6,09 \%$ \\
\hline $\begin{array}{l}\text { Privredna banka } \\
\text { Zagreb }\end{array}$ & $7,21 \%$ & $5,35 \%$ & $5,51 \%$ & $1,69 \%$ & $12,57 \%$ & $10,49 \%$ & $9,75 \%$ & $\begin{array}{r}12,82 \% \\
\text { (MAX) } \\
\end{array}$ & $8,18 \%$ \\
\hline $\begin{array}{l}\text { Raiffeisenbank } \\
\text { Austria }\end{array}$ & $6,70 \%$ & $5,17 \%$ & $6,09 \%$ & $-6,00 \%$ & $10,34 \%$ & $8,88 \%$ & $5,18 \%$ & $9,37 \%$ & $5,72 \%$ \\
\hline $\begin{array}{l}\text { Erste\&Steiermär- } \\
\text { kische Bank }\end{array}$ & $6,94 \%$ & $0,99 \%$ & $3,23 \%$ & $\begin{array}{r}-16,5 \% \\
(\mathrm{MIN}) \\
\end{array}$ & $9,32 \%$ & $9,09 \%$ & $10,63 \%$ & $8,98 \%$ & $4,08 \%$ \\
\hline $\begin{array}{l}\text { OTP banka } \\
\text { (Société } \\
\text { Générale-Split. } \\
\text { banka/Splitska } \\
\text { banka) }\end{array}$ & $\begin{array}{l}6,54 \% \\
2,69 \%\end{array}$ & $\begin{array}{l}4,05 \% \\
1,01 \%\end{array}$ & $\begin{array}{l}8,86 \% \\
5,29 \%\end{array}$ & $\begin{array}{r}-4,69 \% \\
3,42 \%\end{array}$ & $\begin{array}{l}6,86 \% \\
9,74 \%\end{array}$ & $\begin{array}{r}1,04 \% \\
-2,42 \%\end{array}$ & $2,80 \%$ & $9,34 \%$ & $4,35 \%$ \\
\hline $\begin{array}{l}\text { RH bankovni } \\
\text { sustav - prosjek }\end{array}$ & $4,82 \%$ & $0,85 \%$ & $2,76 \%$ & $-8,75 \%$ & $9,60 \%$ & $5,92 \%$ & $8,49 \%$ & $9,87 \%$ & $4,20 \%$ \\
\hline
\end{tabular}

Izvor: HNB (2012-2020), Statistički podaci i Izabrane banke (2012-2019), Financijski izvještaji.

Promatrano razdoblje obilježio je i trend zamjetnijeg snižavanja bankovnih kamatnih stopa te postupno smanjivanje udjela loših kredita nakon 2014., odnosno nakon dužeg razdoblja njihova izraženijeg rasta uz najvišu vrijednost dosegnutu u 2014. godini, što se sveukupno odrazilo na smanjivanje pokazatelja neto kamatne marže (NIM). Unatoč tome, postoje i razdoblja u kojima rastu neto kamatni prihodi, većinom zbog ušteda na kamatnim troškovima uslijed smanjenja kamatnih stopa, što je posljedično dovelo do blaže oscilacije neto kamatne marže. U nastavku (tablica VII) prikazani su rezultati analize pokazatelja neto kamatne marže banaka iz uzorka usporedno s rezultatima ostvarenim na razini ukupnog bankovnog sektora.

Tablica VII: Neto kamatna marža (NIM) pet najvećih banaka u Republici Hrvatskoj i prosjek hrvatskog bankovnog sustava, 2012. - 2019.

\begin{tabular}{|c|c|c|c|c|c|c|c|c|c|}
\hline & 2012. & 2013. & 2014. & 2015. & 2016. & 2017. & 2018. & 2019. & Prosjek \\
\hline Zagrebačka banka & $2,53 \%$ & $2,33 \%$ & $2,50 \%$ & $2,49 \%$ & $2,60 \%$ & $2,66 \%$ & $2,36 \%$ & $2,33 \%$ & $2,47 \%$ \\
\hline $\begin{array}{l}\text { Privredna banka } \\
\text { Zagreb }\end{array}$ & $3,23 \%$ & $3,27 \%$ & $3,10 \%$ & $3,17 \%$ & $3,24 \%$ & $3,14 \%$ & $2,66 \%$ & $2,50 \%$ & $3,04 \%$ \\
\hline Raiffeisenbank Austria & $3,35 \%$ & $3,38 \%$ & $3,37 \%$ & $2,98 \%$ & $2,86 \%$ & $2,73 \%$ & $2,48 \%$ & $2,43 \%$ & $2,95 \%$ \\
\hline $\begin{array}{l}\text { Erste\&Steiermärkische } \\
\text { Bank }\end{array}$ & $2,82 \%$ & $2,57 \%$ & $2,67 \%$ & $2,77 \%$ & $2,82 \%$ & $2,90 \%$ & $2,69 \%$ & $2,52 \%$ & $2,72 \%$ \\
\hline $\begin{array}{l}\text { OTP banka } \\
\text { (Société Générale- } \\
\text { Splitska banka/Splitska } \\
\text { banka) }\end{array}$ & $\begin{array}{l}3,19 \% \\
2,85 \%\end{array}$ & $\begin{array}{l}3,05 \% \\
2,34 \%\end{array}$ & $\begin{array}{l}2,55 \% \\
2,49 \%\end{array}$ & $\begin{array}{l}3,13 \% \\
2,98 \%\end{array}$ & $\begin{array}{l}3,47 \% \\
(\mathrm{MAX}) \\
2,90 \%\end{array}$ & $\begin{array}{l}2,85 \% \\
2,82 \%\end{array}$ & $\begin{array}{r}1,42 \% \\
(\mathrm{MIN}) \\
-\end{array}$ & $2,71 \%$ & $2,80 \%$ \\
\hline $\begin{array}{l}\text { RH bankovni sustav - } \\
\text { prosjek }\end{array}$ & $2,70 \%$ & $2,50 \%$ & $2,60 \%$ & $2,70 \%$ & $2,80 \%$ & $2,80 \%$ & $2,40 \%$ & $\mathrm{n} / \mathrm{a}$ & $2,64 \%$ \\
\hline
\end{tabular}

Izvor: HNB (2012-2020), Statistički podaci i Izabrane banke (2012-2019), Financijski izvještaji. 
U promatranom razdoblju među svim promatranim velikim bankama, ali i u odnosu na prosjek cijelog bankovnog sektora, ističe se Privredna banka Zagreb kao vodeća prema ostvarenoj prosječnoj razini neto kamatne marže, no maksimum ovog pokazatelja ostvarila je OTP banka 2016. godine, dok je Raiffeisenbank Austria do 2015. godine ostvarivala najviše vrijednosti pokazatelja. Dodatno, samo je Zagrebačka banka među svim promatranim bankama ostvarila najniži prosječan rezultat neto kamatne marže u usporedbi s prosjekom čitavog bankovnog sektora, a najnižu vrijednost pokazatelja, pojedinačno promatrano, ostvarila je OTP banka 2018. godine. Ipak, valja uzeti u obzir da je ta godina za banku bila izazovna s obzirom na kompleksan proces pripajanja Splitske banke, što se odrazilo na račun dobiti i gubitka, no samo kratkoročno. S obzirom na navedeno, ako se zanemari rezultat OTP banke za tu godinu, Zagrebačka banka je ta koja je u 2013. i u 2019. ostvarila najniže rezultate promatranog pokazatelja, ali i najnižu prosječnu vrijednost za čitavo promatrano razdoblje, te je jedina ostvarila vrijednost neto kamatne marže nižu i od prosječne vrijednosti pokazatelja na razini čitavog bankovnog sektora. U konačnici, OTP banka je jedina banka koja je 2019. godinu završila rastom neto kamatne marže, što je i rezultat dovršetka potpune integracije OTP banke sa Splitskom bankom. Ipak, valja naglasiti da su sve banke iz uzorka ostvarivale zadovoljavajuće razine neto kamatne marže kroz gotovo čitav promatrani period.

Pokazatelj troškovne efikasnosti ukazuje na optimalno upravljanje troškovima. Prosječna troškovna efikasnost (CIR) (tablica VIII) ističe Zagrebačku banku kao najefikasniju u promatranome razdoblju s obzirom na ostvarenu najnižu prosječnu vrijednost pokazatelja, ali i pojedinačno najnižu u 2018. godini. Privredna banka Zagreb slijedi Zagrebačku banku po efikasnosti, a što je očekivano i s obzirom na veličinu banke te ostvarene razine drugih promatranih pokazatelja. Dodatno, jedino su te dvije banke ostvarile bolji prosječan rezultat od prosjeka čitavog bankovnog sektora za čitavo promatrano razdoblje.

Tablica VIII: Troškovna efikasnost (CIR) pet najvećih banaka u Republici Hrvatskoj i prosjek hrvatskog bankovnog sustava, 2012. - 2019 .

\begin{tabular}{|l|c|c|c|c|c|c|c|c|c|}
\hline & 2012. & 2013. & 2014 & 2015. & 2016. & 2017 & 2018. & 2019. & Prosjek \\
\hline Zagrebačka banka & $42,25 \%$ & $43,80 \%$ & $40,23 \%$ & $48,27 \%$ & $37,97 \%$ & $42,48 \%$ & $\begin{array}{c}37,30 \% \\
(\mathrm{MIN})\end{array}$ & $38,47 \%$ & $41,35 \%$ \\
\hline $\begin{array}{l}\text { Privredna banka } \\
\text { Zagreb }\end{array}$ & $46,26 \%$ & $48,73 \%$ & $51,53 \%$ & $47,30 \%$ & $39,57 \%$ & $40,16 \%$ & $46,16 \%$ & $37,69 \%$ & $44,67 \%$ \\
\hline Raiffeisenbank Austria & $50,62 \%$ & $51,73 \%$ & $53,18 \%$ & $56,77 \%$ & $95,12 \%$ & $76,79 \%$ & $65,34 \%$ & $58,74 \%$ & $63,54 \%$ \\
\hline $\begin{array}{l}\text { Erste\&Steiermärkische } \\
\text { Bank }\end{array}$ & $39,01 \%$ & $43,73 \%$ & $39,42 \%$ & $\begin{array}{l}99,68 \% \\
(\mathrm{MAX})\end{array}$ & $47,79 \%$ & $46,38 \%$ & $48,40 \%$ & $59,00 \%$ & $52,93 \%$ \\
\hline $\begin{array}{l}\text { OTP banka } \\
\text { (Société Générale- } \\
\begin{array}{l}\text { Split. banka/Splitska } \\
\text { banka) }\end{array}\end{array}$ & $51,07 \%$ & $63,13 \%$ & $57,20 \%$ & $61,52 \%$ & $54,04 \%$ & $71,99 \%$ & $69,05 \%$ & $63,93 \%$ & $62,74 \%$ \\
\hline $\begin{array}{l}\text { RH bankovni sustav - } \\
\text { prosjek }\end{array}$ & $51,80 \%$ & $52,00 \%$ & $51,30 \%$ & $51,70 \%$ & $45,00 \%$ & $46,70 \%$ & $47,80 \%$ & $46,32 \%$ & $49,01 \%$ \\
\hline
\end{tabular}

Izvor: HNB (2012-2020), Statistički podaci i Izabrane banke (2012-2019), Financijski izvještaji.

Premda je i Erste\&Steiermärkische Bank promatrano razdoblje započela s dobrim razinama troškovne efikasnosti, one su postupno rasle uslijed pogoršanja rezultata poslo- 
vanja u odnosu na početak razdoblja. U konačnici, Erste\&Steiermärkische Bank pojedinačno promatrano, ali i u usporedbi s ostalim bankama, postiže najlošiji rezultat troškovne efikasnosti i to 2015. godine, s obzirom na visoke troškove konverzije stambenih kredita u švicarskim francima u kredite u eurima te posljedični utjecaj i učinke takvih zbivanja na ukupne troškove poslovanja banke. Raiffeisenbank Austria pak u 2016. i 2017. godini, a OTP banka u 2017. godini također ostvaruju najnepovoljnije vrijednosti troškovne efikasnosti, slijedeći Erste\&Steiermärkische Bank. Kod OTP banke je takav rezultat posljedica procesa okrupnjavanja, te se u narednim godinama pokazatelj troškovne efikasnosti poboljšao s obzirom na trend spuštanja na nešto niže razine. Ipak, pokazatelj troškovne efikasnosti iznad $60 \%$ ukazuje na nedovoljnu efikasnost i na značajniji potencijal za bolje upravljanje troškovima u bankama općenito.

Omjer zajmova i depozita (LDR) (tablica IX), općenito promatrano, ukazuje na visoku likvidnost banaka iz uzorka, odnosno višak neiskorištenih sredstava, a isto se može zapaziti i na razini ukupnog bankovnog sektora u čitavom promatranom razdoblju, što pak ukazuje na neiskorišten kreditni potencijal. Posljedica je to usporavanja kreditne aktivnosti banaka uslijed postrožavanja kreditnih uvjeta u postkriznom razdoblju, ali i čišćenja bilanci banaka od loših kredita. Posljedično, omjer zajmova i depozita ima kontinuirani trend smanjenja sve do 2018. godine kada dolazi do njegovih blažih korekcija, ali samo kod manjeg dijela banaka, što se tek blago odrazilo na rast njegove prosječne godišnje vrijednosti na razini ukupnog bankovnog sektora.

Tablica IX: Omjer zajmova i depozita (LDR) pet najvećih banaka u Republici Hrvatskoj i prosjek hrvatskog bankovnog sustava, 2012. - 2019.

\begin{tabular}{|c|c|c|c|c|c|c|c|c|c|}
\hline & 2012. & 2013. & 2014. & 2015. & 2016. & 2017. & 2018. & 2019. & Prosjek \\
\hline $\begin{array}{l}\text { Zagrebačka } \\
\text { banka }\end{array}$ & $106,1 \%$ & $104,1 \%$ & $108,2 \%$ & $98,42 \%$ & $93,70 \%$ & $85,86 \%$ & $75,05 \%$ & $73,31 \%$ & $93,10 \%$ \\
\hline $\begin{array}{l}\text { Privredna banka } \\
\text { Zagreb }\end{array}$ & $110,6 \%$ & $106,5 \%$ & $95,76 \%$ & $87,02 \%$ & $85,43 \%$ & $79,08 \%$ & $81,63 \%$ & $76,97 \%$ & $90,37 \%$ \\
\hline $\begin{array}{l}\text { Raiffeisenbank } \\
\text { Austria }\end{array}$ & $105,7 \%$ & $104,8 \%$ & $89,11 \%$ & $78,88 \%$ & $73,92 \%$ & $71,99 \%$ & $\begin{array}{r}67,72 \% \\
(\mathrm{MIN})\end{array}$ & $70,54 \%$ & $82,84 \%$ \\
\hline $\begin{array}{l}\text { Erste\&Steier- } \\
\text { märkische Bank }\end{array}$ & $85,4 \%$ & $91,4 \%$ & $88,33 \%$ & $87,65 \%$ & $87,27 \%$ & $85,51 \%$ & $86,61 \%$ & $84,41 \%$ & $87,07 \%$ \\
\hline $\begin{array}{l}\text { OTP banka } \\
\text { (Société } \\
\text { Générale-Split. } \\
\text { banka/Splitska } \\
\text { banka) }\end{array}$ & $\begin{array}{r}85,9 \% \\
112,59 \% \\
(\mathrm{MAX})\end{array}$ & $\begin{array}{r}86,2 \% \\
98,74 \%\end{array}$ & $\begin{array}{r}88,56 \% \\
120,37 \%\end{array}$ & $\begin{array}{r}89,85 \% \\
109,92 \%\end{array}$ & $\begin{array}{r}82,83 \% \\
104,66 \%\end{array}$ & $\begin{array}{l}82,19 \% \\
98,36 \%\end{array}$ & $\begin{array}{r}78,82 \% \\
-\end{array}$ & $\begin{array}{r}78,68 \% \\
-\end{array}$ & $84,13 \%$ \\
\hline $\begin{array}{l}\text { RH bankovni } \\
\text { sustav - prosjek }\end{array}$ & $98,3 \%$ & $93,2 \%$ & $88,50 \%$ & $83,94 \%$ & $79,90 \%$ & $76,10 \%$ & $79,98 \%$ & $\mathrm{n} / \mathrm{a}$ & $85,71 \%$ \\
\hline
\end{tabular}

Izvor: HNB (2012-2020), Statistički podaci i Izabrane banke (2012-2019), Financijski izvještaji.

Na temelju provedene analize može se zaključiti kako trendovi kretanja odabranih računovodstvenih pokazatelja poslovanja na razini cijelog bankovnog sektora (prosječne vrijednosti) ne odstupaju značajnije kad se promatraju pojedinačno na razini banaka iz uzorka, što potvrđuje značaj velikih banaka u hrvatskom bankovnom sustavu s obzirom na visok stupanj koncentracije. 
Veća međusobna odstupanja promatranih pokazatelja poslovanja banaka zabilježena su u godinama izraženijih izvanrednih okolnosti o kojima je bila riječ u 3. dijelu rada, a primarno uslijed konverzije kredita indeksiranih u švicarskim francima u kredite u eurima i poteškoća u poslovanju Agrokor grupe, koje su različito utjecale na odabrane pokazatelje, ovisno o razini izloženosti pojedinih banaka. Dodatno, promatrani period značajnije je obilježilo čišćenje bilanci banaka od djelomično i potpuno nenaplativih kredita nakon razdoblja izraženijeg rasta njihova udjela u ukupnom kreditnom portfelju, te usporavanje kreditne aktivnosti uslijed postrožavanja kreditnih uvjeta u postkriznom razdoblju, što je produžilo razdoblje recesije u Hrvatskoj i u konačnici se značajnije odrazilo i na pokazatelje poslovanja kako velikih banaka koje su u fokusu analize u ovom radu tako i na razini čitavog bankovnog sektora.

S obzirom na navedeno, može se zaključiti kako je specifično makroekonomsko, financijsko i regulatorno okruženje u promatranom razdoblju imalo značajniji utjecaj na pokazatelje poslovanja velikih banaka, što potvrđuju rezultati analize provedene u radu.

\section{ZAKLJUČAK}

Hrvatski je bankovni sektor u proteklom desetljeću doživio brojne promjene pod utjecajem ekonomskih i financijskih zbivanja te postrožene regulacije kao posljedice negativnih učinaka financijske krize 2008. godine, a dodatno i stupanjem na snagu preostalih regulatornih promjena povezanih s pristupanjem Hrvatske Europskoj uniji. Sve navedeno značajno je utjecalo na poslovnu politiku i pokazatelje poslovanja banaka koje su bile aktivne u tom razdoblju. Postroženi kreditni uvjeti, rast djelomično nadoknadivih i potpuno nenadoknadivih kredita, iznimno visoka likvidnost i visok udio neuposlenih sredstava ostavili su posljedice na poslovne rezultate te na pokazatelje profitabilnosti, efikasnosti i likvidnosti poslovanja banaka, a dodatan izraženiji učinak na poslovanje imali su i konverzija stambenih kredita indeksiranih u švicarskim francima u kredite indeksirane u eurima 2015. godine te posljedice izloženosti pojedinih banaka prema Agrokor grupi u 2018. godini.

Razdoblje nakon 2012. godine obilježilo je smanjenje broja banaka, čišćenje aktive od loših plasmana, dokapitalizacija te pad prihoda i dobiti većine banaka na tržištu. U promatranom razdoblju broj banaka smanjio se za trećinu: provedeno je pet pripajanja među bankama uz jedno pripajanje od strane inozemne matične banke, pet banaka je promijenilo ime u postupcima stjecanja odnosno promjene vlasništva, a nad tri banke je pokrenut postupak likvidacije ili stečajni postupak, dok je dvjema bankama oduzeto odobrenje za rad. Uslijed ovih strukturnih promjena indeks koncentracije postao je još viši i dodatno naglasio tržišnu dominaciju nekolicine najvećih banaka, redom članica ili podružnica velikih međunarodnih bankovnih grupacija, koje su imale važnu ulogu u okrupnjavanju.

Trendovi kretanja analiziranih računovodstvenih pokazatelja poslovanja u promatranom razdoblju na razini cijelog bankovnog sektora (prosječne vrijednosti) pak ne odstupaju značajnije od rezultata ostvarenih na razini pojedinačnih banaka iz uzorka, što potvrđuje značaj velikih banaka u hrvatskom bankovnom sustavu s obzirom na visok stupanj koncentracije. Veća međusobna odstupanja kod velikih banaka zabilježena su u godinama izraženijih izvanrednih okolnosti (primarno uslijed konverzije kredita indeksiranih u švicarskim 
francima u kredite u eurima i poteškoća u poslovanju Agrokor grupe), koje su različito utjecale na odabrane pokazatelje poslovanja ovisno o razini izloženosti pojedinih banaka. Stoga je stabilnost poslovanja primarno velikih banaka od ključne važnosti za stabilnost ukupnog bankovnog sektora, ali i ukupnog financijskog sektora i cjelokupne ekonomije s obzirom na izraženu bankocentričnost i ovisnost sudionika o bankovnim kreditima kao najznačajnijim eksternim izvorom financiranja.

\section{LITERATURA}

1. Berger, A. N., Handcock, D. and Humphery, D. (1993). Bank efficiency derived from the profit function. U: Journal of Banking and Finance, Vol. 17 No. 2/3, str. 332-345.

2. Drake, L. (2001). Efficiency and productivity change in UK banking. U: Applied FE, Vol. 11 No. 5, str. 557-571.

3. Erste\&Steiermarkische Bank (2012-2019). Financijski izvještaj. (dostupno na: https:// www.erstebank.hr/hr/o-nama/financijska-izvjesca, pristupljeno 4. srpnja 2020.)

4. European Banking Federation [EBF] (2020). Banking in Europe: Facts \& Figures 2020. (dostupno na: https://www.ebf.eu/facts-and-figures/ebf-facts-figures-2020-keydocuments/, pristupljeno 27. siječnja 2021.)

5. European Central Bank [ECB] (2021). Official data. (dostupno na: https://www.ecb. europa.eu/stats/supervisory_prudential_statistics/consolidated_banking_data/html/ index.en.html, pristupljeno 21. siječnja 2021.)

6. Fries, S., Taci, A. (2005). Cost efficiency of banks in transition: Evidence from 289 banks in 15 post-communist countries. U:Journal of Banking and Finance, Vol. 29, str. 55-81.

7. Hrvatska Narodna Banka [HNB] (2012-2019). Bilten o bankama. (dostupno na: https://www.hnb.hr/analize-i-publikacije/redovne-publikacije/bilten-o-bankama, pristupljeno 20. siječnja 2021.)

8. Hrvatska narodna banka [HNB](2012-2020). Statistički podaci.(dostupno na: https:// www.hnb.hr/statistika/statisticki-podaci/financijski-sektor/druge-monetarne-financijske-institucije/kreditne-institucije/bankovna-supervizija/pokazatelji-poslovanja-kreditnih-institucija, pristupljeno 20. siječnja 2021.)

9. Hrvatska Narodna Banka [HNB] (2020). Standardni prezentacijski format (dostupno na: https://www.hnb.hr/analize-i-publikacije/redovne-publikacije/spf, pristupljeno 20. siječnja 2021.)

10. Hrvatska Narodna Banka [HNB] (2021). Pokazatelji poslovanja kreditnih institucija (dostupno na: https://www.hnb.hr/statistika/statisticki-podaci/financijski-sektor/druge-monetarne-financijske-institucije/kreditne-institucije/bankovna-supervizija/pokazatelji-poslovanja-kreditnih-institucija, pristupljeno 5. veljače 2021.)

11. SeeNews (2020). Top 100 Banks. (dostupno na: https://top100.seenews.com/rankings/ top-100-banks/, pristupljeno 17. siječnja 2021.)

12. Statista (2020). Statistical data. (dostupno na: https://www.statista.com/statistics/383406/leading-europe-banks-by-total-assets/, pristupljeno 17. siječnja 2021.) 
13. Jemrić, I., Vujčić, B. (2002). Efficiency of Banks in Croatia: A DEA Approach. CNB WP, No. 7

14. Jurčević, B., Mihelja Žaja, M. (2013). Banks and insurance companies efficiency indicators in the period of financial crisis: the case of the Republic of Croatia. U: Economic research, Vol.26, No. 1, str. 203-224.

15. Novickyte, L., Droždz, J. (2018) Measuring the Efficiency in the Lithuanian Banking Sector: The DEA Application. U: International Journal of Financial Studies, Vol. 6, No. 2, Art. no. 37, str. 1-15.

16. OTP banka (2012-2019). Financijski izvještaj. (dostupno na: https://www.otpbanka. hr/hr/o-nama/godisnja-izvjesca, pristupljeno 3. srpnja 2020.)

17. Privredna banka Zagreb (2012-2019). Financijski izvještaj. (dostupno na: https://corp. pbz.hr/hr/financijska-izvjesca-press, pristupljeno 2. srpnja 2020.)

18. Raiffeisenbank (2012-2019). Financijski izvještaj. (dostupno na: https://www.rba.hr/onama/financijski-pokazatelji, pristupljeno 4. srpnja 2020.)

19. Regulation (EU) No 575/2013 (CRR)

20. Řepková, I. (2014). Efficiency of the Czech banking sector employing the DEA window analysis approach. U:Procedia Economics and Finance, Vol. 12, str.587-596.

21. Shawtari, F.A., Salem, M.A., Bakhit, I. (2018). Decomposition of efficiency using DEA window analysis: A comparative evidence from Islamic and conventional banks.U: An International Journal, Vol.25, No.6, str. 1681-1705

22. Šverko, I., Pavlović, A., Vukas J. (2012.). Analiza poslovanja malih banaka u Republici Hrvatskoj. U: Privredna kretanja i ekonomska politika, Vol. 133, str. 27-45

23. Tuškan Sjauš, B. (2020). The importance and business performance efficiency of small banks: case of the Republic of Croatia. U: Proceedings of FEB 11th International Odyssey Conference on Economics and Business, Faculty of Economics and Business University of Zagreb, Vol. 2, No. 1, str. 399-410 (doi: 10.22598/odyssey)

24. Tuškan Sjauš, B., Mihelja Žaja, M. (2020). Croatian banking and insurance industry: overview of cost efficiency performance after accession to the European Union. U: Proceedings of 9th International Scientific Symposium Region Enterpreneurship Development, Faculty of Economics and Business University of Osijek, 480-497 (http:// www.efos.unios.hr/red/wp-content/uploads/sites/20/2020/06/RED-2020-Proceedings_.pdf)

25. Tuškan, B., Stojanović A. (2016). Measurement of cost efficiency in the European banking industry. U: Croatian Operational Research Review, Vol. 7, No. 1, 47-66

26. Zagrebačka banka (2012-2019). Financijski izvještaj. (dostupno na: https://www.zaba. hr/home/o-nama/investitori/financijski-izvjestaji/, pristupljeno 3. srpnja 2020.)

27. Žager, K., Sačer Mamić, I., Sever, S., Žager, S. (2009). Analiza financijskih izvještaja, Masmedia. 